TITLE:

\title{
ANATOMY OF EMBLETONIA GRACILIS PAUCIPAPILLATA N. SSP. FROM OSAKA BAY, JAPAN (NUDIBRANCHIA-EOLIDOIDEA)
}

\section{$\operatorname{AUTHOR}(S)$ :}

Baba, Kikutaro; Hamatani, Iwao

\section{CITATION:}

Baba, Kikutaro .... [et al]. ANATOMY OF EMBLETONIA GRACILIS PAUCIPAPILLATA N. SSP. FROM OSAKA BAY, JAPAN (NUDIBRANCHIA-EOLIDOIDEA). PUBLICATIONS OF THE SETO MARINE BIOLOGICAL LABORATORY 1963, 11(2): 399-402

\section{ISSUE DATE:}

1963-12-31

URL:

http://hdl.handle.net/2433/175335

RIGHT: 


\title{
ANATOMY OF EMBLETONIA GRACILIS PAUCIPAPILLATA N. SSP. FROM OSAKA BAY, JAPAN (NUDIBRANCHIA-EOLIDOIDEA)
}

\author{
KIKUTARO BABA and Iwao HAMATANI \\ Biological Laboratory, Osaka Gakugei University, Osaka
}

With Plate XVII

Our specimens previously referred to the New Caledonian species, Embletonia gracilis (Tergipedidae), have been revised and re-identified as follows:

1. Embletonia gracilis RISBEC, 1928. Yotsumata-minoumiushi

Embletonia gracile BABA, 1959, pp. 335-336, pl. 29, figs. A-E.

Loc. : Ogashima, Sagami Bay (Aug. 22, 1949, 1 sp., ${ }^{\text {) }}$ coll. by the Biological Laboratory, Imperial Household).

Gills in a single row of 7-8 papillae on each side (liver-diverticula within the gills pale yellow).

2. Embletonia gracilis paucipapillata n. ssp. Izumi-yotsumata-minoumiushi (n. n.)

Embletonia gracile BABA, 1959, p. 336, pl. 29, figs. F-I.

Type loc.: Tannowa, Osaka Bay (Mar. 28, 1959, 2 sps., coll. by the junior author).

Gills in a single row of $4-5$ papillae on each side (liver-diverticula within the gills vivid orange-yellow).

\section{Anatomical accounts of Embletonia gracilis paucipapillata}

Besides the type series, a number of additional specimens of this form have been obtained from the type locality: Mar. 17, 1960, 4 sps.; Mar. 28-29, 1960, 5 sps. ; Apr. 30, 1960, 2 sps.; Mar. 18, 1961, 2 sps.; Apr. 30, 1961, 2 sps. All the specimens were found on the shore of Tannowa, Osaka Bay. Six out of these specimens were prepared in serial transverse and horizontal sections for the examination of the internal organs.

1) Another specimen was collected by Dr. Masuoki HoRIKosir from the vicinity of the Misaki Marine Biological Laboratory, Sagami Bay, on June 19, 1946 (length $7 \mathrm{~mm}$; gills in 8 pairs, each papilla creamy orange).

Publ. Seto Mar. Biol. Lab., XI (2), 1963. (Article 23) 
The animals, matured, attain the maximum length of 5-6 $\mathrm{mm}$ in the extended condition (Code Ac of Risso-Dominguez, 1963). The body-colour is as described previously (integument slightly yellowish white covered with opaque white dots which tend to collect together to form short, irregular, opaque white striations over the back and papillae; an opaque white making on the head in the centre; liver-diverticula within the branchial papillae tinged with vivid orange-yellow). The general body-form is also as shown previously. The branchial papillae number almost always $4-5$ on each side.

The pharynx has a pair of simple band-like salivary glands. Within the haemocoele there are 3, somewhat eosinophile gland masses, the function of which being left undermined. The jaw-edge is provided with a row of about 8-13 feeble denticles. The radula formula is $70-80 \times 0.1 .0$. The teeth are as recorded before. The stomach consists of two chambers, the anterior and the posterior. The right liver (and the left-sided partner) has 2 canals, each containing a single papilla. The anus is acleioproctic, and the nephroproct preanal. The genital orifice lies between and below the first and the second papillae on the right side. The four apical twigs of the branchial papillae have each a simplified cnidosac filled with nematocysts ${ }^{1}$. The whole liver system is glandular, the ciliated epithelium being confined to the digestive tract proper (oesophagus, stomach and intestine). The kidney is a simply elongated sac without branching; in front it bifurcates in two horns. The reno-pericardial canal is also simple (wall not folded). The male orifice and the female one are united. The penis is cucumber-shaped. Structurally it is a prostate, and the whole organ is formed of eosinophile gland cells. No stylet is found at the tip of the penis. The ovo-testes, 8-13 in number in different individuals, are arranged in two longitudinal rows within the haemocoele.

The genus Embletonia was established by ALDER and HANCOCK, in 1851, with brief characterization based on the type, E. pulchra (A. \& H., 1844), from the Atlantic $^{2}$ (see also Pruvot-Fol, 1954, pp. 410-411, fig. 159). The information as to the internal anatomy of this species was increased to some extent thanks to MARCUS, 1958, pp. 92-96, pl. 18. In the general body-form and the liver branching, the species gracilis shows affinity to pulchra, but the prostatic and unarmed penis of the former differs from the conical, muscular and armed penis of the latter (A. \& H., 1851, fam. 3, pl. 38, fig. 9; see also ODHNER, 1939, pp. 75-76; MArcus, 1957, p. 467, 1958, p. 93, pl. 18, fig. 8). At present it must be remembered that classifying the species gracilis in the genus Embletonia defined by A. \& H., 1851, is only provisional. Here the Embletoninae is accepted as a subfamily of the Cuthonidae with some questions (cf. Рruvot-Fol, 1954, p. 410).

1) Occurrence of 'Nesselplatten' or 'pads of cnidocysts' on the tips of the branchial papillae in E. pulchra from Helgoland was called attention to by Marcus (1958, p. 94, 1960, p. 181).

2) E. faurei LABBÉ, 1923, Atlantic, is not known anatomically (cf. PrUvoT-FoL, 1954, p. 411; MARCUS, 1957, p. 467). 


\section{REFERENCES}

(Continued to BABA, 1963)

Alder, J. \& HaNCOCK, A. 1851. Monograph of the British nudibranchiate Mollusca. Pt. 5.

BABA, K. 1959. A new record of an interesting species, Embletonia gracile RISBEC, from Japan (Nudibranchia-Eolidacea). Publ. Seto Mar. Biol. Lab., vol. 7, no. 3.

- 1963. The anatomy of Cuthona futairo n. sp. (=C. bicolor of BABA, 1933) (Nudibranchia-Eolidoidea). Publ, Seto Mar. Biol. Lab., vol. 11, no. 1.

LABBÉ, A. 1923. Description sommaire de cinq nouvelles espèces d'éolidiens trouvées à la Station du Croisic. Bull. Soc. Sci. Nat. l'Ouest France, ser. 4, tom. 3.

Marcus, Er. 1957. On Opisthobranchia from Brazil (2). Journ. Linn. Soc. London, Zool., vol. 43, no. 292.

Marcus, Ev. \& Er. 1958. Opisthobranchia aus dem Schill von Helgoland. Kieler Meeresf., Bd. 14, Hft. 1.

1960. Opisthobranchs from American Atlantic warm waters. Bull. Mar. Sci. Gulf \& Carib., vol. 10, no. 2.

Risso-Dominguez, C. J. 1963. Measuring nudibranchs: a standardization for descriptive purposes. Proc. Malac. Soc. London, vol. 35, pt. 5. 


\section{EXPLANATION OF PLATE XVII}

Figs. 1-12. Embletonia gracilis paucipapillata from Tannowa, Osaka Bay, Japan.

Fig. 1. Digestive system in the body, diagrammatic. a. right liver, b. genital orifice, c. intestine, d. longitudinal stripe of the subcutaneous basophile gland, e. nephroproct, f. anus, g. left posterior liver, h. posterior chamber of stomach, i. left anterior liver, j. anterior chamber of stomach, k. salivary gland, 1. pharynx. The glandular part of the liver system is thickly dotted with black.

Fig. 2. A branchial papilla $(\times 30)$. a. apical cnidosac filled with nematocysts. The canals between the liver-diverticulum and the cnidosacs could not be traced clearly.

Fig. 3. Denticulation of the jaw-edge $(\times 270)$.

Fig. 4. A radula tooth with a protruded median cusp and 3-4 flanking denticles.

Fig. 5. Central nervous system $(\times 70)$. a. ganglionated nerve to the lip (inner branch) and cephalic lobe (outer branch), b. rhinophorial nerve and its ganglion, c. cerebro-pleural ganglion, d. pedal ganglion.

Fig. 6. Kidney. a. reno-pericardial canal, b. nephroproct.

Fig. 7. Genital system in the body, diagrammatic. a. eosinophile gland masses of unknown function, b. right and left ducts united in front. No opening of the common duct thus formed, could not be determined.

Fig. 8. Genital system, diagrammatic. a. prostatic penis with strong cilia internally, b. penis sheath, c. common genital orifice, d. outer oviduct, e. spermatheca, f. albumen gland, g. ampulla, h. hermaphrodite duct, i. mucous gland.

Fig. 9. An ovo-testis $(\times 70)$. a. hermaphrodite duct.

Fig. 10. Transverse section of the body on level of the anus $(\times 30)$. a. pericardium, b. kidney, c. hermaphrodite duct, d. stripe of subcutaneous basophile gland, e. anus, f. ovo-testis, g. left posterior liver.

Fig. 11. Part of the transverse section on level of the nephroproct $(\times 60)$. a. auricle, b. kidney, c. stripe of subcutaneous basophile gland, d. nerve cord, e. nephroproct, f. rectum.

Fig. 12. Transverse section of the body passing through the somewhat contracted head-part $(\times 30)$. a. left anterior liver, b. central nervous system (below, a pair of buccal ganglia are found), c. anterior chamber of stomach, d. oesophagus, e. salivary glands and their ducts, f. apex of the prostatic penis, g. right liver, h. pharynx with paired jaw-plates, i. left anterior eosinophile gland mass. 
Publ. Seto Mar. Biol. Lab., XI, 2 (1963)

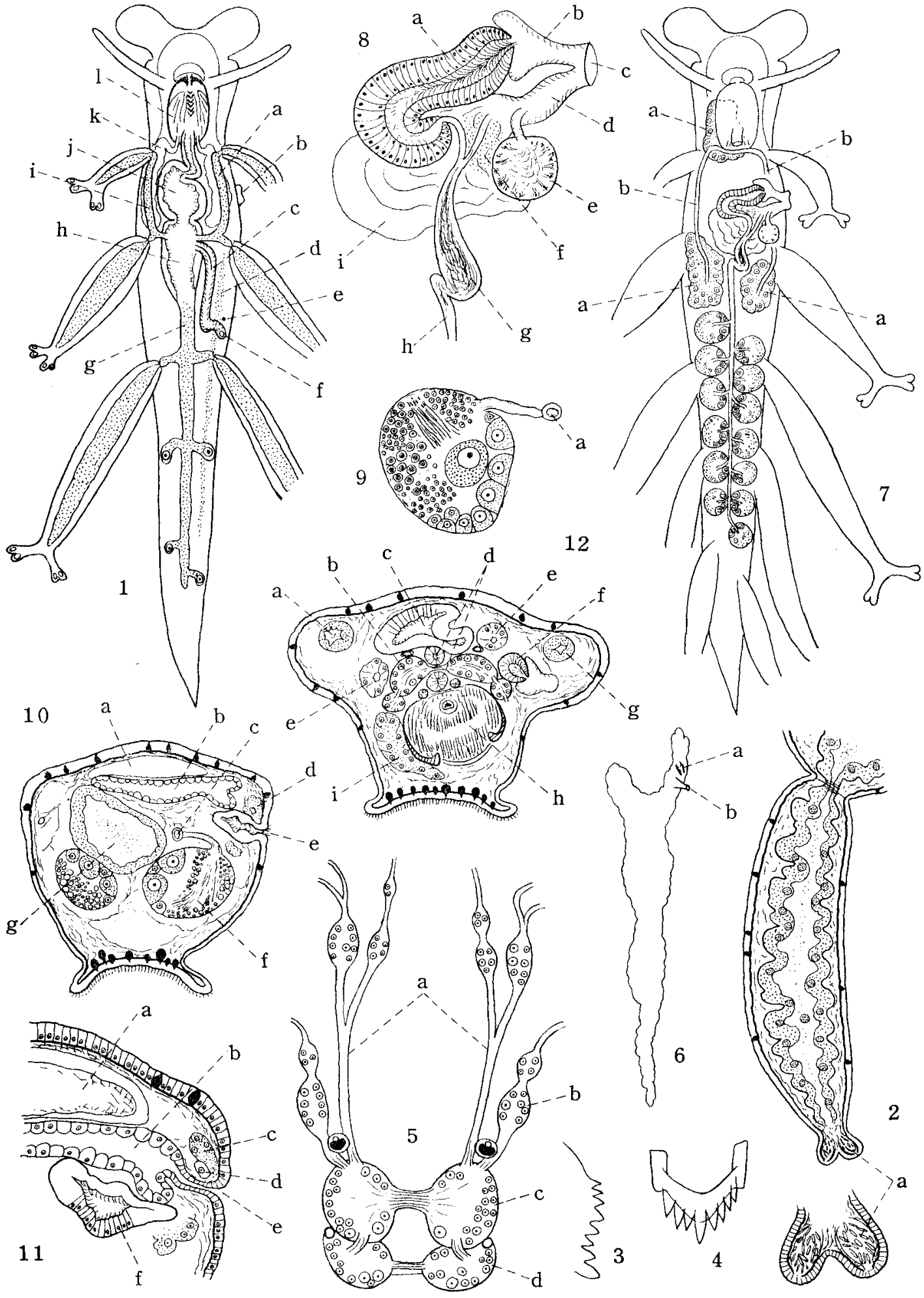

K. Baba And I. Hamatani : Anatomy of Embletonia gRacilis paucipapillata 